\title{
（345）王延材の異方性におよ经す $\mathrm{MnS}$ の量・大をさ・形状の影響
}

神戸製鋼所 中央研究所

○金子晃司井上毅 工博 木下修司

1 緒 言

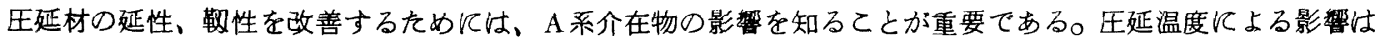
すでルnSの形状で整理でさるととを報告したので、今回は MnSの量と大ささの異なった供試材を用い、环延条 件で MnS の形状を変化させて、L．C．Z方向の引張り性質と衝擊性質などを調査した結果である。

\section{2 実験方法}

供試材恃表 1 亿示すどとく $\mathrm{S}$ 量を変化させた $90 \mathrm{Kg}$ 鋼塊であるが、MnSの大をさを変えるため発熱鋳型と金型 で造塊した。 A，B，C，D鋼の研磨面における MnSの平均径は約 $10 \mu$ で、 $\mathrm{E}$ 鋼のそれは約 $4 \mu$ である。臣延 条件は加熱温度を $1250 \mathrm{C}$ と $900 \mathrm{c}$ とし、王延中の温度低下 表 1 供試材の化学成分（\%) を防ぐため中間加熱を行をった。圧下比は $3.5 〜 16$ の間で 変化させ、920 C × $1 \mathrm{hr}$ の焼㞭らし処理をしてL．C．Z方 向の引張り試験とシャルビー衝㩓試験を行なった。をた各試 験片の破断面に占める $\mathrm{MnS}$ と $\mathrm{A}_{2} \mathrm{O}$ の面積率在特性 X 線像加 ら求め、延性との関係を調べた。

\section{3 実験結果}

\begin{tabular}{|c|c|c|c|c|c|c|c|}
\hline & $\mathrm{C}$ & $\mathrm{Si}$ & $\mathrm{M}_{\mathrm{n}}$ & $\mathrm{P}$ & $\mathrm{S}$ & $\mathrm{A} \ell$ & 錐型 \\
\hline $\mathrm{A}$ & 0.14 & 0.26 & 0.60 & 0.004 & 0.003 & 0.047 & \\
\hline $\mathrm{B}$ & 0.12 & 0.20 & 0.60 & 0.006 & 0.008 & 0.038 \\
\hline $\mathrm{C}$ & 0.12 & 0.27 & 0.76 & 0.006 & 0.018 & 0.044 & 発䓡 \\
\hline $\mathrm{D}$ & 0.15 & 0.26 & 0.64 & 0.006 & 0.045 & 0.044 & \\
\hline $\mathrm{E}$ & 0.13 & 0.44 & 0.74 & 0.006 & 0.023 & 0.026 & 金型 \\
\hline
\end{tabular}

(1)压延機の圧延方向に平行な研磨面における $\mathrm{MnS}$ の長さ/厚さの比を王下比に対してプロットすると図1が得ら れる。MnS は低温压延の方が変形しやすく、MnSの大きさす大きい方が変形量が多い。

(2)同一匡延条件におけるシェルフェネルギーは、S 量あるいは介在物清净度の低下で改善される。

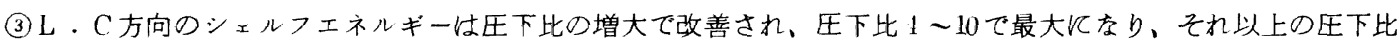
では劣化する。延性の改善は鋳造組織の破壊で、劣化は MnS の影蟹が大きいためと考えられる。

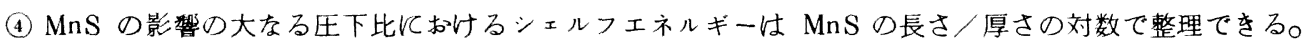

(5) L.C方向の破断ひずみは L.C方向のシェルフェネルギー程介在物の影響を受けないが、Z方向破断ひずみ は乙方向シェルフエネルギーと同様に介在物の影響が大さい。

(6)シェルフエネルギ一、破断ひずみとも供試材のS 量、圧延条件、試験方向に関係なく破断面に占める MnS と

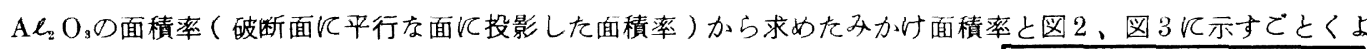

い相関がある。

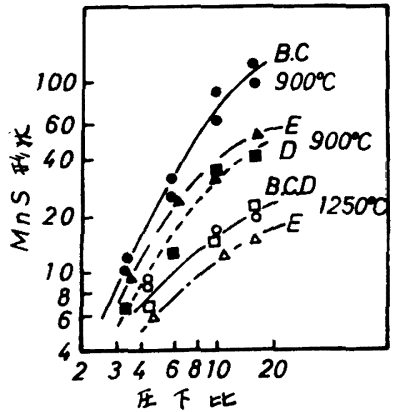

図 $1 \mathrm{MnS}$ の形状変化

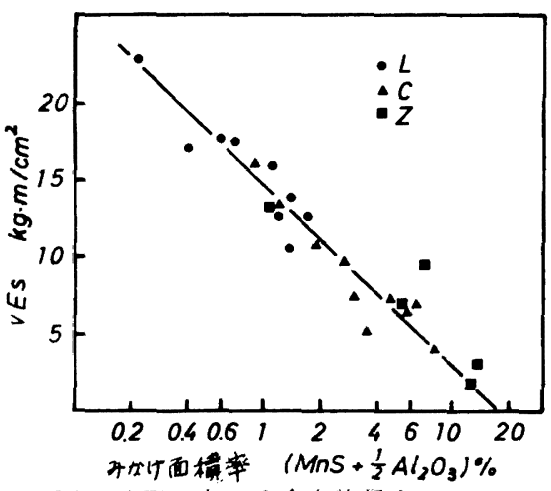

図2 破面に占妨名在物量と シェルフェネルギー

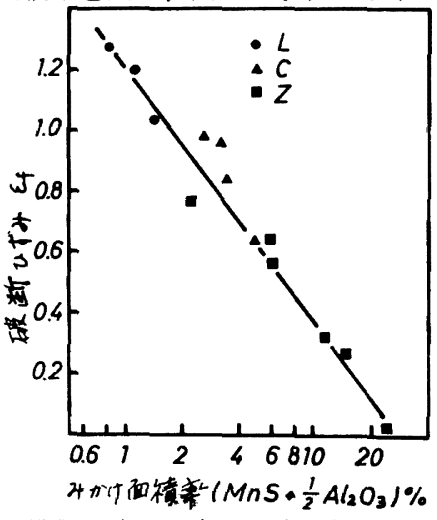

図3破面に占奶介在物量 と破断ひずみ 


\section{（346） S M50 龬のZZ方向脆性破壊特性に及ほす S 量の影響}

\section{1. 緒 言}

海洋構造物等における如く、板厚方向に応力の加わ る棈造の溶接部で発生し易いラメラテアに関連して 前報 $^{1)}$ では S 量の異なる 2 種類の S M 50 鋼 Z 方向 脆性破壊および疲労伝播特性について報告した。 今回は S 量を 6 レベルに変えた S M 50 鋼を用いて Z方向のシャルピー試験、COD試験、低温引張試験 等を行なって脆性破壊特性に及ぼす $\mathrm{S}$ 量の影響を検討するとと もに、ラメラテアを含む溶接継手の脆性破壊試験をも行ない、 小型試験との対応を検討した。

\section{2. 実験方法}

供試材は $\mathrm{S}$ 量を $0.003 \sim 0.025 \%$ 範囲で変化させた 6 種 類の S M 50 商用鋼 $\mathrm{A} \sim \mathrm{F}$ であり、その化学成分を表 1 に示す。 各供試鋼板 ( $32 \mathrm{~mm}$ 厚) の溶接部材よりシャルピー試験片、 COD試験片 $(25 \times 50 \times 300 \mathrm{~m} \mathrm{~m})$ 、低温引張試験片 $6 \mathrm{~m} \mathrm{~m}$ ) を採取し、Z方向試験に供した。C鋼の溶接部には 逆歪によりラメラテアを発生させ、この素材よりラメラテアを 含む大型引張試験片（100×350×600 m m) を採取し 低温での脆性破壊試験に供した。

\section{3 . 実験結果}

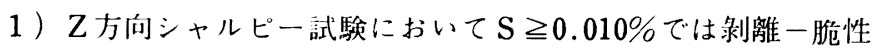
破壊であり、S $\leqq 0.005 \%$ では通常の延性一脆性破壊である。 シェルフエネルギーは $\mathrm{S}$ 量の減少に伴い単調に增加する。

2） $0^{\circ} \mathrm{C}$ でのZ方向限界 C O D 值は図 1 に示すように介在物の 長さの和と良い相関が認められる。 $0{ }^{\circ} \mathrm{C}$ 以上における C O D 值

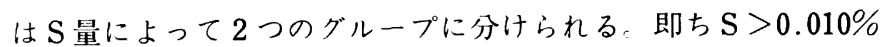

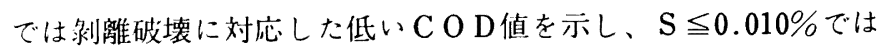
延性破壊に対応した高いCOD值を示す。

3 ) 平滑試験片を用いた低温引張試験の結果を図 2 に示す。 降伏応力は $\mathrm{S}$ 量に依存しないが、引張強さは各温度とも $\mathrm{S}$ 量の 增加とともに低下し、しかも降伏応力以下での破壊が生じる。

4 ) ラメラテアを有する溶接継手の低温大型引張試験を行なった 結果、久陷先端での限界 C O D 值と小型三点曲げ試験で得られ た限界 C O D值の間には良い一致が見られた。

\section{参考文献}
（1）小林、成本他
: 鉄と鋼 61

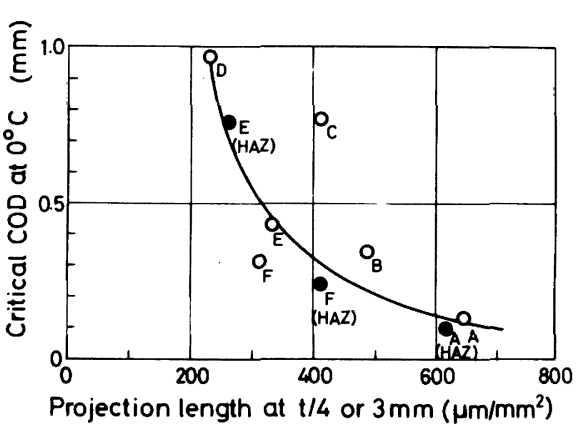

図 1. 限界 $\mathrm{COD}$ と介在物長さの 関係

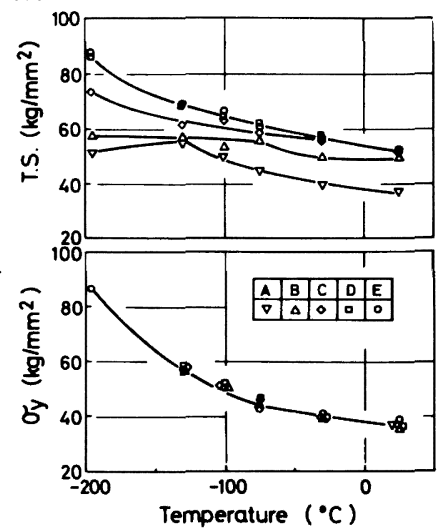

図 2. 降伏応力、引張強さの 温度依存性（Z方向） 


\title{
（347）完全球状硫化物の高張力鋼板の耐衝撃特性におよぼす効果
}

\author{
新日本製鐵森基礎研究所工博島田春夫，○哺原義明
}

\section{I 緒 言}

希土類金属を添加して硫化物の形態を調整し，構造用鋼材の異方性を改善させる試みが各所で行われ ているが，まだ形態の完全球状化と溶製方法に不充分な点が見られる。したがって,ての点を種々検討 し， C e の添加を工夫するてと飞ょって完全球状の C e オキシ硫化物を得る方法を確立した。そてて今回， その方法を用いて溶接性高張力鋼板のコントロールド・ローリング材につんて珙方性の改善効果の検討 を行なったので、その結果を報告する。

\section{II 実験方法ならびに結果}

試料（第 1 表飞示す）は $10 \mathrm{~K}$, 真空溶解炉て溶製し, コントロールド・ローリングを行なった後にL方向と C 方向の衝撃試験結果（第1図に示す）に上って異方性の 第 1 表 試料の組成

\begin{tabular}{|c|c|c|c|c|c|c|c|c|c|}
\hline & $c$ & $\mathbf{S}_{i}$ & $\mathrm{~s}_{1}$ & $P$ & $s$ & $\mathrm{Co}$ & $\mathrm{Al}$ & $\mathrm{Nb}$ & $\mathrm{V}$ \\
\hline 戝 & a11 & 031 & 1.16 & 0.916 & 0.007 & $<0005$ & 0012 & 003 & 30 \\
\hline & 010 & 033 & 1.18 & 0.016 & 0006 & 025 & 0.020 & 0.03 & \\
\hline
\end{tabular}
評価を行った。Ce無添加の試料(A) の硫化物注伸状の MnS（写真 1 $\mathrm{a}$ 照) て, c方向の衝晸值を低 下させているが，Ceを 0.025 \%含 試料(B)の硫化物は完全球状のCe 才キシ硫化物（宁真 1 - b 参照） 飞去っており， C 方向の性質が大 幅改善され，異方性が無くなっ ている。主として，(1)C方向の shelf•energy が $5 \mathrm{~kg}-m$ 改善され. 乚う向との差が臣とんど無い。(2) 遷移温度は L方向で $20 \mathrm{C}, \mathrm{C}$ 方向 で 40 C改善された。(3) 熱サイクル 再現試験後の試料におらても良好 な性質を示した。なお，衝撃試験
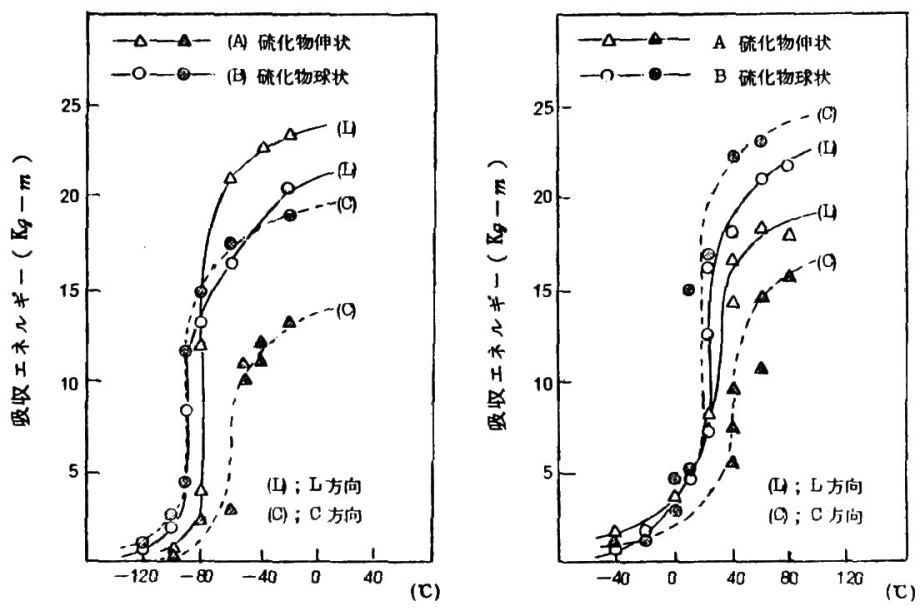

図 1. 衝撃特性に与える球状硫化物 図 2. 衝撃特性に与える球状硫化 の効果 物の奻果 (熱サイクル処理後) 後の試料( $-20 \mathrm{C}, \mathrm{C}$ 方向) の破面を走査電子影微鏡を用 んて観察した結果を写真1一a， b示すか，試料(A)て は MnS D存在している個所は周囲のディンプルに比較し て破面が拡大されているが，試料(B)ではCeオキシ硫化物 の存在している個所は周囲のディンブル面と差が無く、 介在物による影響が小さい事がわかる。

III 結 言

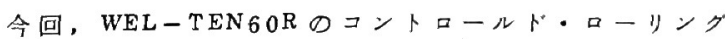
村に内在する伸状の $\mathrm{MnS}$ を完全球状の $\mathrm{Ce}$ オキシ硫化物 にすることにより，異方性が大幅に改善されることを実証したが，この方法は他の構造用銅材において 広範囲に応用でさる可能性がある。 


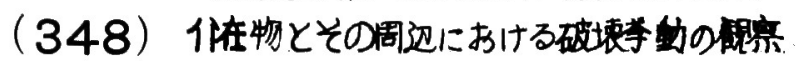

引張り応力下に执ける銅中非金属介在物の破壊への影䅧一第4 報 千葉工業大学

大学院 O脽㷊哲雄

工博岗本田厚正

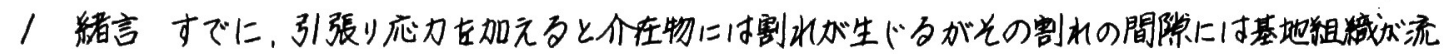

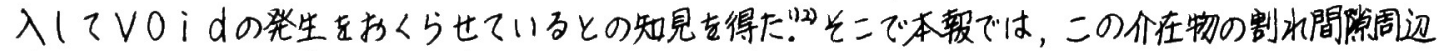

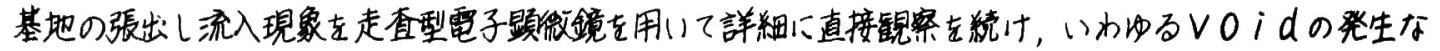
らびに合体から破断にいたる過程を明白にしようとくた。

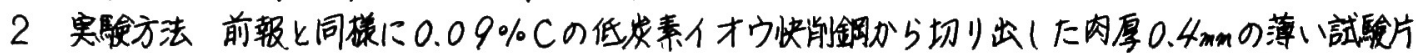

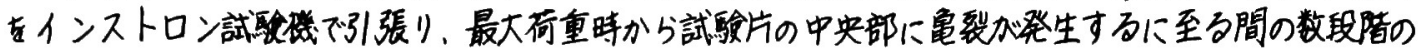

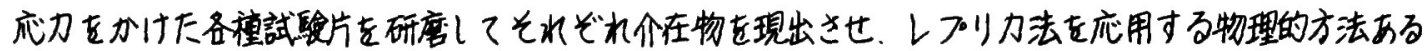

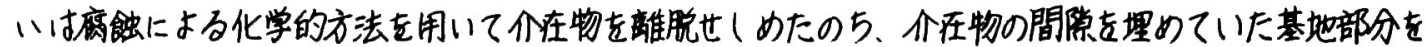

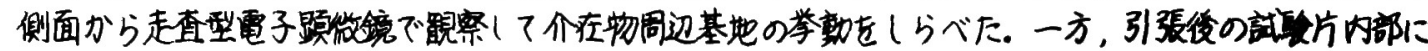

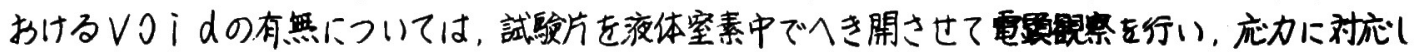
EVOidの発生成長状態追跡した。

3 实駩狤果 最大荷重時の引張り㐫力をかけた試验片内部に存在する介

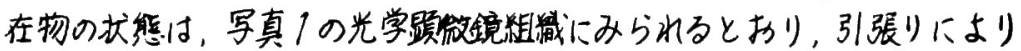
生に゙た介在物の揢水の間悲に，写真中A部のような基地の流入があリ，前 報どおりの現泉であった．B部はレプリ力法を㐫用して介在物を離脱させ たあとであるが，二の部分を知の方向から電㩆鼠察たものが写真2で ある。二れによると、試验片の厚みオ向の上，下から基地加張出( 、，中 間で接合(たと思われる面が明りょうに認められ，最大何重までの引張り における作物の割れ間陌への基地の流入過程が明らかに示されている。 引張り荷重が最大荷重を二えると介在物の間陪气うめる基地部分にも若千 の空隍がみられるようになっ上。写真了は破断黾裂近傍の状態を示才が， 介在物間隐に一たん流入した基地卡はく㒕の生じている二とがわかる。

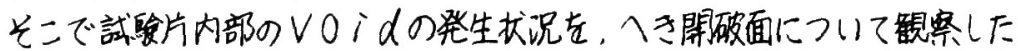
ところ，引張りによって延性破壊皇裂与生じていなかった部分すなわち液

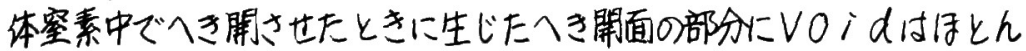
どみられなかったのに效して，同じへき開面でも延性破壊面の位置に近付 くにつれてV0idの数は增大してゆき，VOidの発生は試騟片のneckingにより大きな多軸応力の働く破断二゙く寸前の延性破面近傍の部分上，

はしめて生成才るものと牥れた。さらにVO门dの合体成長については。 たとえば写真4のように介在物密度の高いと二ろでは，VOidの合体が

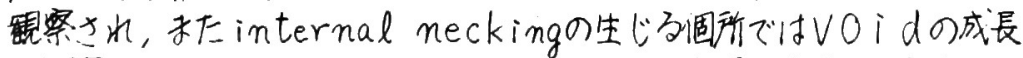

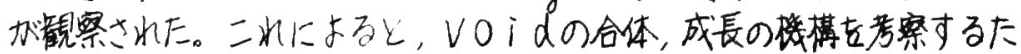
めには，介物固辺のマク口的応力解折では不十分であり，介在物個々下 対するミク口的な応力犹態古明らかに(なければならないと考えられる。

文献 1)用田 山本藤: 鉄と鎆6/(1975)4S282

2)用田 山本 藤森:鉄と鋼6/(1975)/2 S785

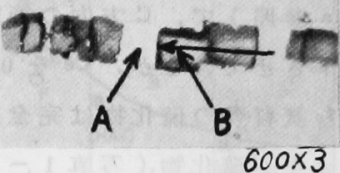

写真1引張後の介在物

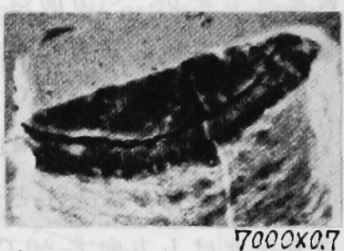

写真2 介在物間㳟への基 地流入状说

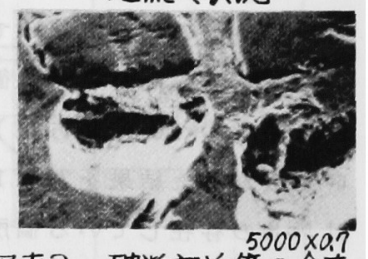

写真3 破断部近傍の库 物

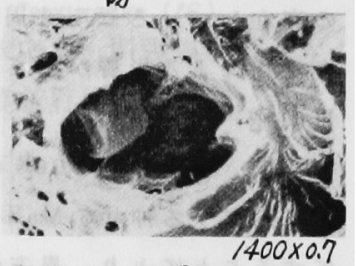

写真4 入き開面にみられ る介在物上Void 
$669.14 .018 .292: 669.85 / .86: 669.781: 621.791 .05$

539.55: 620.192.45: 669.112.228.1

\section{（349）ＲＥＭ－B 系鋼の溶接ボンド部の靶性と超微細介在物の関係}

川崎製鉄㑛技術研究所

○石川正明 上田修三 松下萬愛

平井征夫 工博 船越督己

\section{1 緒言}

実験室溶解材を用いた実験により、希土類元素（RE M）と B を適量添加した $40 \sim 60 \mathrm{~kg} / m m^{2}$ 級 鋼の大入熱溶接ボンド部は、溶接熱サイクル中の $\gamma \rightarrow \alpha$ 変態に際して R E M系介在物の表面に析出した B Nがフェライトの核生成サイトを提供するため、微細なフェライト・パーライト組織となり、切欠靸性が

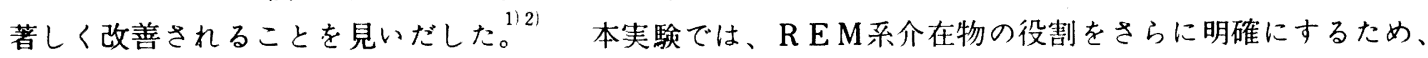
実験室溶解材および工場生産材を用いて、ボンド部における微細フェライトの形成と鋼中の超微細介在物 の個数の関係を調查した。さらに後者の試験材について、ボンド部の広範囲な小型および大型脆性破壊 試験を行なった。

\section{2 実験方法}

試験材の目標成分は $0.12 \% \mathrm{C}-0.25 \% \mathrm{~S}$ i $-1.45 \% \mathrm{M} \mathrm{n}-$

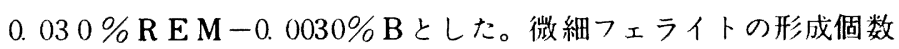
は、入熱 $230 \mathrm{~K} \mathrm{~J} / \mathrm{cm}$ 溶接ボンド部相当の再現熱サイクルの 冷却途上 $650{ }^{\circ} \mathrm{C}$ から急冷した試料の倍率 100 倍の光顕写真を用 いて、Hand-Counting 法で測定した。また介在物の粒度別分布 はQTMを用いて調べた。さらに片面サブマージアーク溶接、エ レクトロガス溶接、およびエレクトロスラグ溶接法による溶接継 手について、シャルピー試験、中央切欠付ディープノッ千試験、温度 勾配型E S S O 試験などを行なった。

\section{3 実験結果}

（1）溶接熱サイクルの冷却中、6 $50{ }^{\circ} \mathrm{C}$ ま゙に $\gamma$ 粒内で形成され る特徵的な微細フェライトの個数は、図 1 のように鋼中の $0.3 \sim 1$ $\mu の$ 超微細介在物個数の增加にほぼ比例して增加する。

（2）いすれれの溶接法の場合も、工場生産した R E M - B 系鋼の溶 接ボンド部の小型および大型脆性破壞特性は、 $\mathrm{S} i-\mathrm{Mn}$ 系鋼にく らへ、、きわめて優れ、その傾向は鋼中の超微細介在物の增加とと もにより一層顕著になる。一例として、片面サブマージアーク溶 接継手のディープノッ千試験の結果を図 2 に示す。脆性破壊の発生 阻止特性は、 $\mathrm{S} i-\mathrm{M}$ 系鋼(B)にくらべて、 R E M-B系鋼 A 1、A 2 ）の方が良好であり、しかも超微細介在物個数の多い鋼 （A１）が少ない鋼（A 2 ）にくらべ、さらに良好である。

これらの実験事実は、REM-B系鋼固有の微細フェライトの核 生成作用 ${ }^{2)}$ と核生成サイトの数の多少から説明できる。

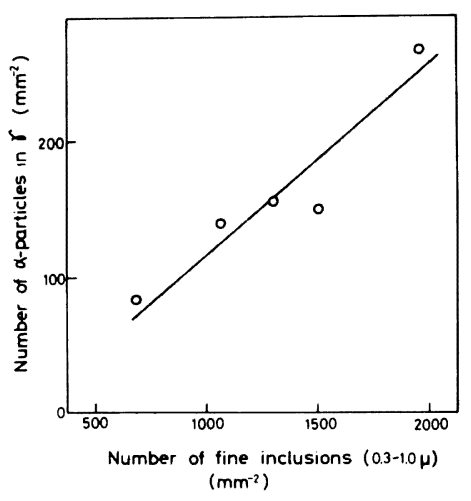

図 1 超微練介在物個数上 $\gamma$ 粒内に 形成される微細フェライトの個 数の関係

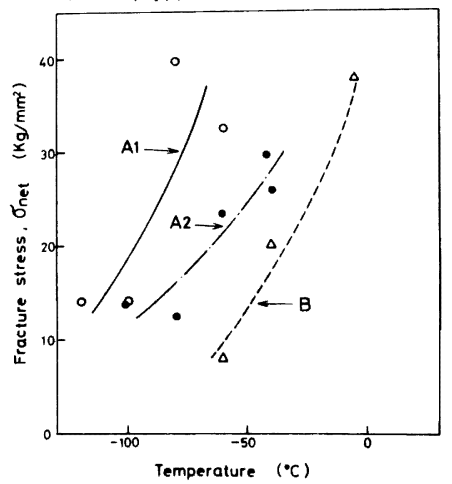

図2 ディーノプッチ試験における 破壊応力の温度依存性

\section{[参考文献]}

1) 上田、船越、田中、腰塚、石川：鉄と銅、6 0 （1 $9774 ）$ S 549

2) 上田、石川、小林、船越：鉄と鋼、6 1 (1 1975 ） 5598 


\title{
（350）鋼板の機械的性質に及ぼす $\mathrm{Mg}$ および $\mathrm{Ca}$ の効果
}

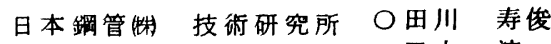 \\ 田中 淳一 \\ 小指軍夫 \\ 天明玄之博 \\ 1. 緒言
}

これまで、Ca処理鋼板の機械特性についての報告は数多いが, $\mathrm{Ca}$ と同族で $\mathrm{O}, \mathrm{S}$ との親和力の强い $\mathrm{Mg}$ 処理鋼板の機械特性について論しられた例はほとんどない。そこで、溶銅中でも比較的安定な Ni-Mg合

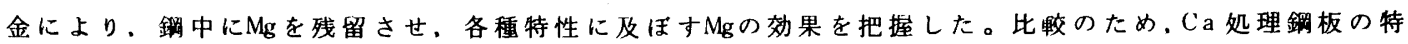
性も併せて調查した。

\section{2. 実駼方法}

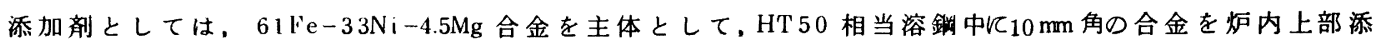
加し，一定時間保持後，造塊した ( $\mathrm{Ni}$ 量は全 $\mathrm{Ch}$ とも同一になるように調整)。Sレベルとしては, 0.005 \%の Low S 材と, $0.015 \%$ High S 材の 2 レベルについて実施した。

縋圧により $12 \mathrm{mmt}$ 蚞で压延し(压下比 : 8), $910^{\circ} \mathrm{C} \times 40$ 茄後空泠の焼準处理を 施して、試験に供した。

さらに、このようにして得た材料に 対し, $900 \sim 1400^{\circ} \mathrm{C}$ の温度に一定時間 保持した埸合の $r$ 粒の粗大化傾向に及

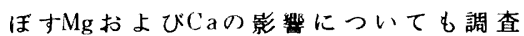
した。

3. 実佒結果抢よび考察

(1) Mg処理およびCa処理により銅板の延 性は、各方向とも向上するが，とくに

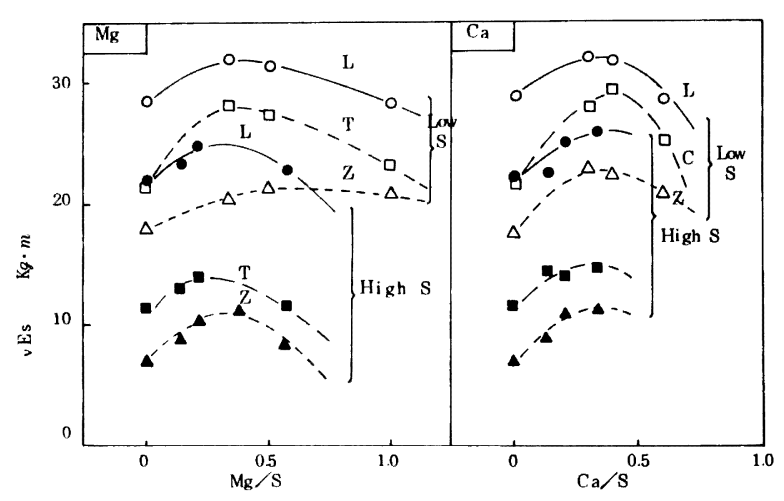

図 1. Mg/S 扰よびCa/SとL,T,Z 方向のvEs の関係 $\mathrm{T}$ 方向の向上が大きい。しかし、Mg、Caの量が過多にな ると、介在物が増加するため延性は低下する。延性 $\max$ のときの $\mathrm{Mg} / \mathrm{S}, \mathrm{Ca} / \mathrm{S}$ の值は, Low $\mathrm{S}$ 材, High S 材とも. ほほ0.3〜0.4になる(図1)。

(2)靶性に関して，L方向はほとんど変化しないが，T方 向において。多少の向上が見られる。

(3) $\mathrm{Mg}$ 処理おょびCa処理鋼板は， $r$ 粒租大化に対する抵抗 が大きい。Low S よりもHighSの方がその効果は大きく、 $\mathrm{Mg}$ 処理 High S 材の 30 分保持の場合, $1300^{\circ} \mathrm{C}$ 以上では, $\mathrm{Ti}$ 添加鋼よりも、その (4) $\mathrm{Mg}$ 処理およびCa処理による延靶性の向上は，介在物 形状制御，分布状热の変化等によるものであり， 長抑制は，Al およびMnを含んだMgあるいはCa の微細

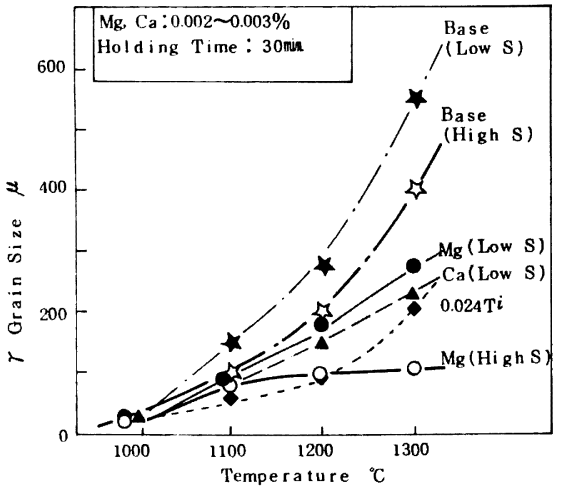

図 2. 高温保持による $r$ 粒径の変化 なOxysulphideによるものであることがわかった。 


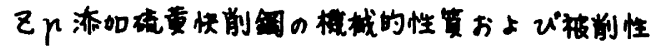

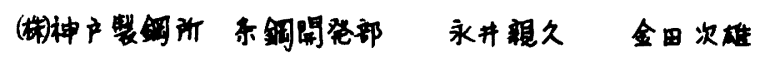

1. 緒 言

川内显。古沢真良山本寿夫

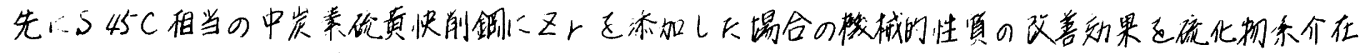

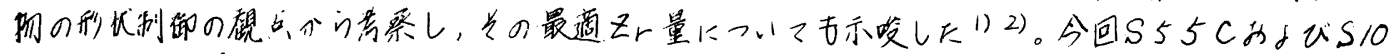

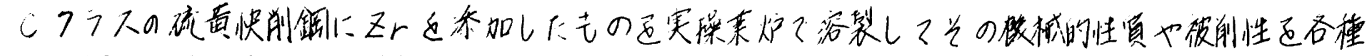

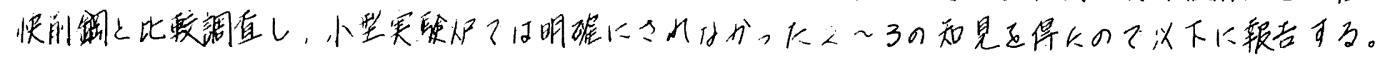
2. 供线销

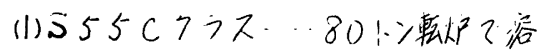

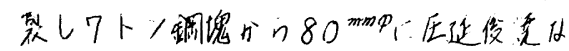

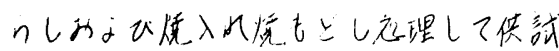
lr.

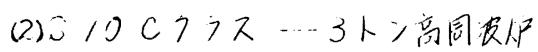

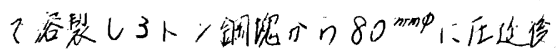
境は的し炎理して供詞した。

谷々の化字戍分䛧民表人に示可。

了。調直絬果。

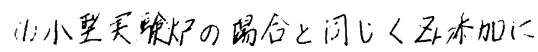

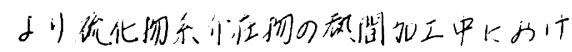

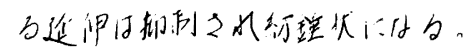

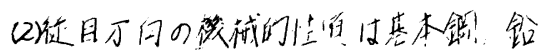

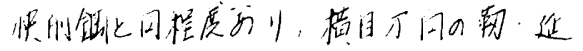

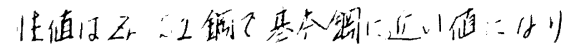

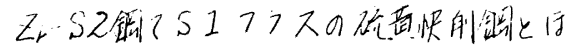
将同程质江为。

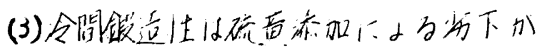

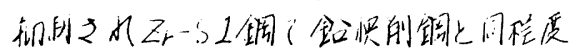
祅方。

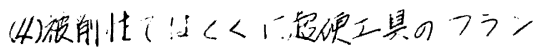

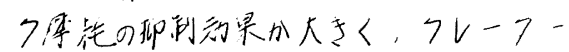

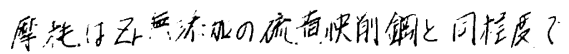

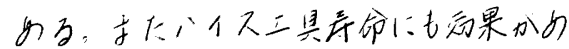
$n ， と<に Z_{r}-2 Z$ 镉てはトリル工具方命

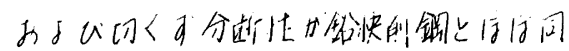

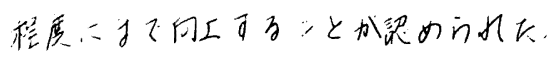
(国1)

\begin{tabular}{|c|c|c|c|c|c|c|c|c|c|}
\hline 急嵫 種 & C & Si & $M_{n}$ & $P$ & S & Cu & $N V_{i}$ & $C_{r}$ & \\
\hline $5 \not z r-3)$ & 0.55 & 0.28 & 0.90 & 2.018 & $0.1 /\}$ & 002 & 0.02 & 0.12 & \\
\hline . S1 & $0.5^{\prime}$ & 0.26 & 0.84 & 000 & 0.055 & 0.01 & 0.01 & 10 & \\
\hline 1 & 0.55 & 21 & 0.95 & 2.018 & 10.051 & 0.01 & 0.01 & 0.12 & \\
\hline 550 & 0.53 & 2.24 & 0.78 & 022 & 0.022 & 1 & 0.02 & 0.11 & \\
\hline $55 \mathrm{CL}$ & 0.54 & 0.24 & 0.73 & $0.01 /$ & 0.020 & 0.102 & 0.02 & 0.12 & $\begin{array}{l}p D \\
0.1\end{array}$ \\
\hline $10 z_{r}-S z$ & 0.09 & 0.30 & 0.94 & 0.009 & 0.108 & 0.01 & 0.01 & 0.01 & \\
\hline $10 Z_{r}-S L$ & 0.10 & 0.27 & 79 & 0.009 & 0.066 & 0.02 & 0.02 & 0.02 & 0. \\
\hline 51 & 0.13 & 0.20 & 0.75 & 0.013 & 0.054 & 0.03 & 0.02 & 0.02 & \\
\hline 100 & 47 & & & & & 0.02 & 0.02 & 0.02 & \\
\hline 100 & & & & & & 4 & 0.01 & .01 & \\
\hline
\end{tabular}

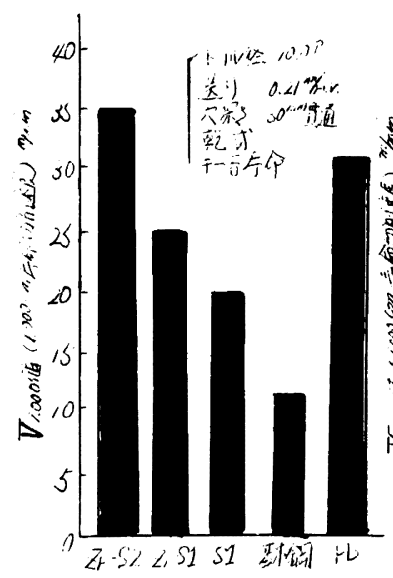

(a) $S 55 C$ ク

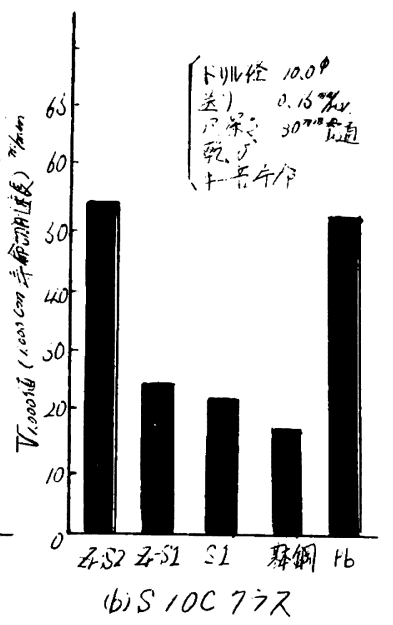

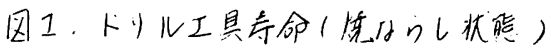

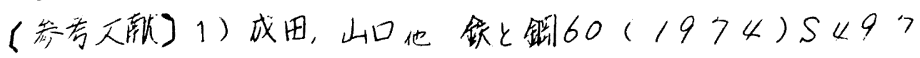

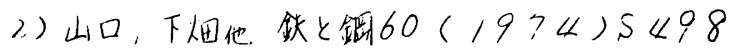


'76-S 352

( 352 ) Ti脱 669.14.018.23: 669.15'295-194

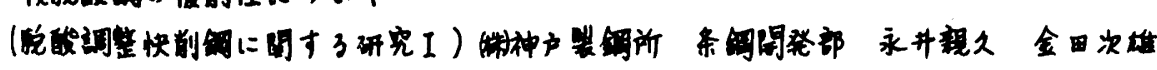

1. 粕言

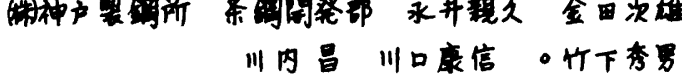 中央研究新松本洋}

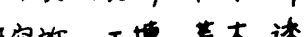

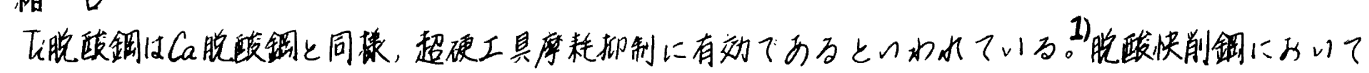

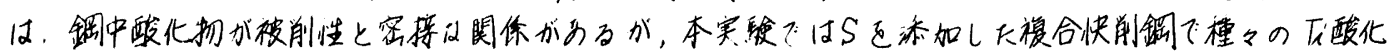
抑を生成子せ被削性との関你を調直した。

2。実駼方法

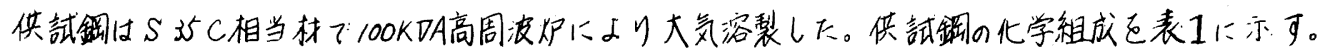

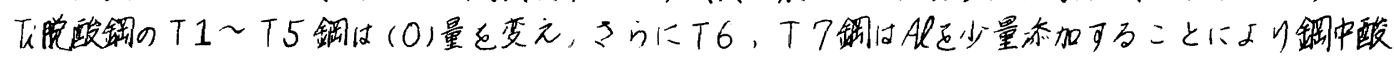

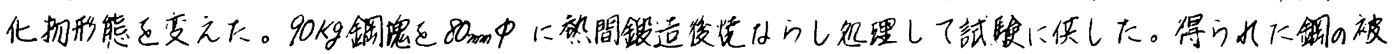

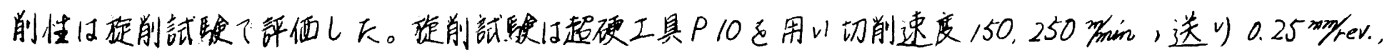

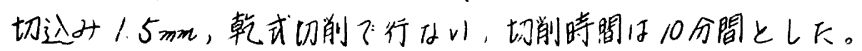

3. 結果

下脱酸錻のT1，T2堸の酸化扬は $T_{i \times} O_{Y}-M_{n} 0$ 系が多く TixOr-MnO系の周

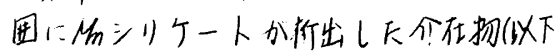

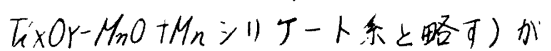

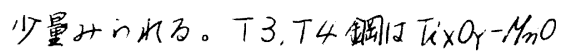
十 Mnシリケート系が主て，T5敛1Mn シリケートが多く TixOY-MnO+Mnシリケ卜系が少量てある。（）量が为く斿ると

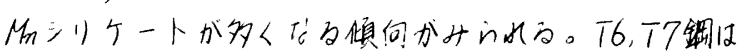

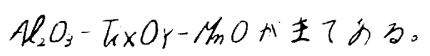

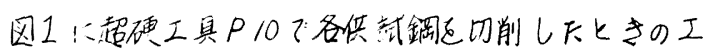
具摩耗(逃げ面摩耗巾) と示可。元脱酸銅間以被削性

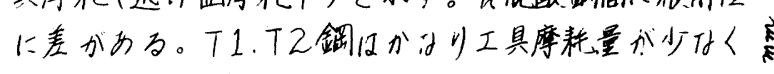

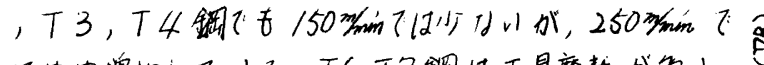

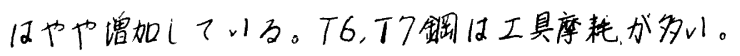

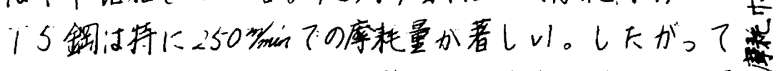

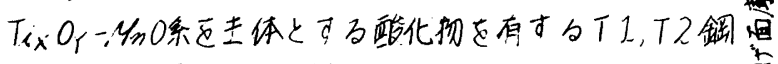

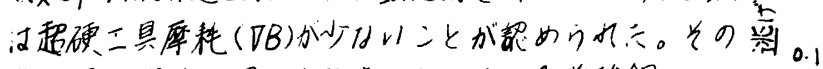

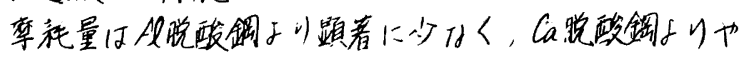
か少付儿傎向がめる。

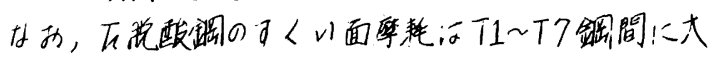

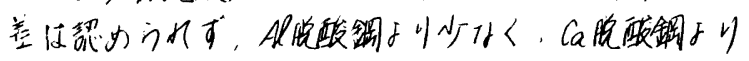

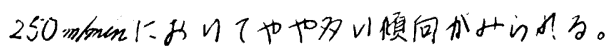

1) 坠木，山本；鋭と船57(1971) S/36

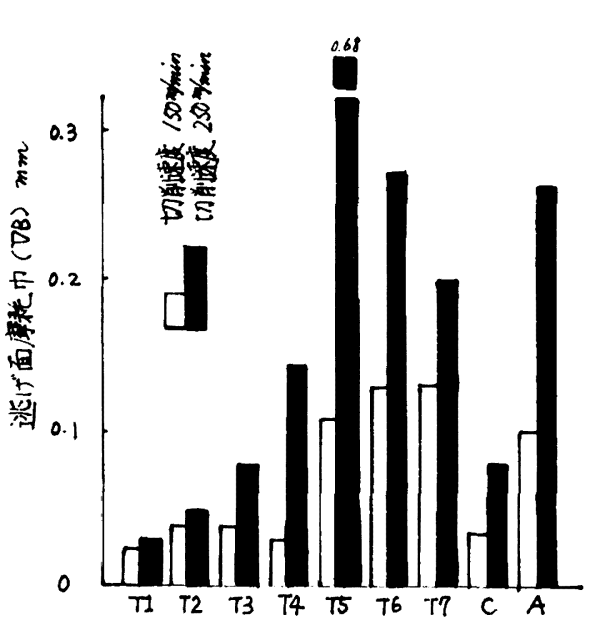

因1. 超硬工具摩耗
表1供試堸の化学組成( Wt \%)

\begin{tabular}{|c|c|c|c|c|c|c|c|c|c|c|}
\hline 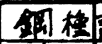 & 往是 & C & $L$ & $n$ & $P$ & $s$ & $\mu$ & a & 12 & \\
\hline 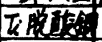 & $T 1$ & 0.32 & 2 & 77 & 77 & 52 & $0 / 3$ & $t$ & & \\
\hline 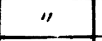 & T2 & 37 & 36 & & & 38 & & & & 008 \\
\hline 1 & T3 & .33 & 0.36 & 7 & 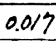 & (142) & & & $t_{r}$ & 2013 \\
\hline 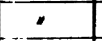 & $T 4$ & 4 & $D$ & & 0.076 & 59 & & $t$ & 002 & $0.0 \%$ \\
\hline " & -1 & & 0 & & 16 & 0.047 & 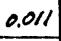 & & $\infty$ & \\
\hline " & 76 & 0.37 & 0.32 & & 017 & $10 \%$ & .014 & {$[2$} & 008 & $0.00 \%$ \\
\hline "I & TY & 0 & 0.35 & 78 & 017 & 0.041 & 0.025 & $t$ & 0008 & 0.015 \\
\hline$x \in x_{x}$ & C & 0.38 & 0.27 & 84 & .005 & 0.062 & $=$ & 9.00 & ea & 0.00 \\
\hline $80^{6} A^{\circ}$ & $\bar{A}$ & 0.38 & 24 & 0.84 & 0.019 & .048 & - & 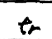 & 0.0 & 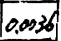 \\
\hline
\end{tabular}




\section{（353）高張力鋼のリブ十字前面すみ肉溶接継手の疲れ強さにおよぼす} 溶接材料 ・ 溶接姿勢の影響 （第 1 報 $: 80 \mathrm{~kg} / \mathrm{mm}^{2}$ 級高張力鋼）

川崎製鉄技術研究所

溶接棒鉄粉工場
○松本重人 小林邦彦

工博 船越督已 田中康浩 坂本 昇 新川耕治

1.緒言：高張力鋼のリプ十字すみ肉溶接継手の疲れ強さに影響を与える最も大きな因子は継手 部の幾何学的形状であることがよく知られており、疲れ強さの改善を目的として余盛止端部を滑らかに するすみ肉溶接の研究が進められている。筆者らは被覆アーク溶接棒による溶接材料および溶接姿勢を 変えることにより余盛止端部が滑らかなリブ十字すみ肉継手を作製しその疲れ試験を実施し、溶接材料 、溶接姿勢が余盛止端形状および疲れ強さに及ほす影響について検討した。

2 . 実験方法：実験に使用した供試材は板厚 $15 \mathrm{~mm}$ の H T 80 でその化学成分および機械的性質を表 1 に 示す。また溶接材料はKS $86 \mathrm{~F}(\mathrm{E}$ タイプ)、KS87(Fタイ 表 1 . 供試材の化学成分および機械的性質 プ) KS106(Gタイプ)、KS116(Hタイプ)の 4 種類を用

\begin{tabular}{|c|c|c|c|c|c|c|c|c|c|}
\hline C & $\mathrm{Si}$ & Mn & $P$ & 5 & $\mathrm{Cu}$ & $\mathrm{Ni}$ & $\mathrm{Cr}$ & Mo & v \\
\hline
\end{tabular}

い、溶接姿勢は水平すみ肉等脚 $(\mathrm{H})$ 、水平すみ肉下肉 $(\mathrm{D})$ おょよ゙下向すみ肉 $(\mathrm{F}) の 3$ 条件とした。疲れ 試験に先立ち各種溶接継手の余盛止端部の止端半径 $\rho$ および余盛角度 $\theta$ を測定した。試験は容量 40 \% ローゼン八ウゼン万能疲労試験機を使用し、繰返し速度 666 c.p.m、応力比 $\mathrm{R}=0$ の完全片振り引張疲 労で行なった。

3 . 実験結果：図 1 に母材、各種リブ十字すみ肉溶 接継手の疲れ試験結果を、図 2 に余盛止端部に生ずる 応力集中率の計算値 ${ }^{1)}$ 、実測値と疲れ限度の関係を示

す。その結果次のことが明らかとなった。

(1)同一溶接姿勢 $\mathrm{H}$ で比較すると溶接材料による相違 は明瞭で 8EH、8HH、8GH 8FH、シリーズの順に疲れ 限度 $\sigma_{\mathrm{w}}$ は向上している。とくに $8 \mathrm{FH} の \sigma_{\mathrm{w}}$ は他のそ れにくらべて著しい改善がみられる。

(2)溶接材料 $\mathrm{F}$ を用い溶接姿勢 $\mathrm{H} 、 \mathrm{~F} 、 \mathrm{D}$ と変えた $\sigma \mathrm{w}$

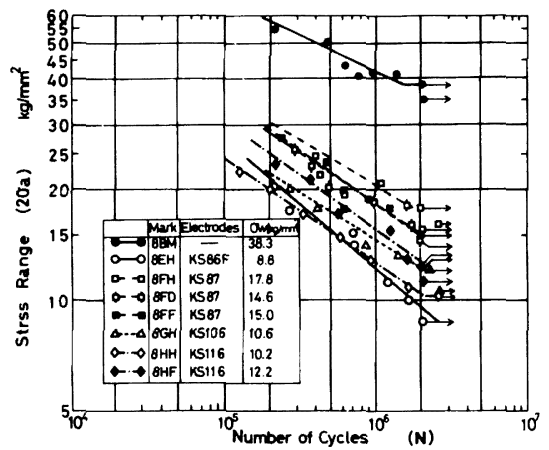

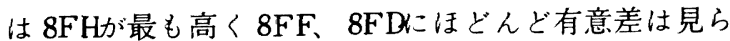
れない。しかし溶接材料 $\mathrm{H}$ を用いて姿勢 $\mathrm{H} 、 \mathrm{~F}$ と変え

図1。各種リブ十字すみ肉溶接継手の $\mathrm{S}^{-} \mathrm{N}$ 曲線

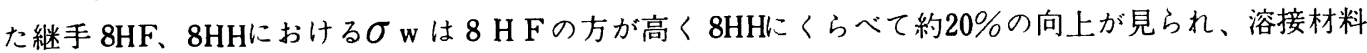
により傾向は異なる。

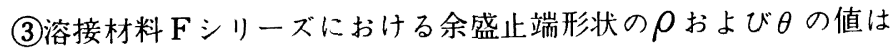
それぞれ0. 3 8. $1 \mathrm{~mm} 、 136 \sim 163,5^{\circ}$ に、他のシリーズのそれは $0,1 \sim 2,3 \mathrm{~mm} 、 96 \sim 151^{\circ}$.に分布した。 $\rho 、 \theta$ の大きいことが F リーズの応力集中率を小さくし、従がって他のシリーズと比べてい ずれも疲れ限度が著しく高い原因となっている。

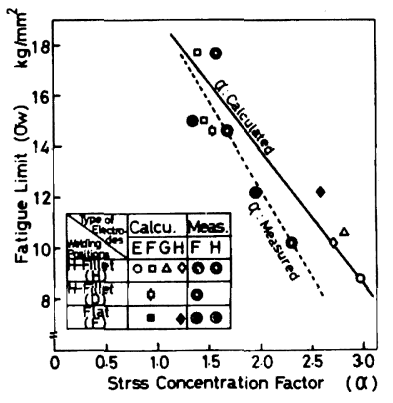

文献1）西田正孝；応力集中、森北出版 図2. 応力集中係数と疲れ限度の関係 
'76-S $354621.771 .237 .016 .3: 621.771 .073: 531.781 .082 .5: 539.431$

（354）冷延ワークロールの疲労損賃

（X線によるロール損傷の研究一I）

新日鐵 君津製鐵所工博 武智 弘難波和郎 ○川崎宏一 古賀国彦 藤原圭三 三堀 勤

1. いきさつ

ストリップ製造原価においてロール費は主要な項目であり削減の努力が続けられている。しかし、压 延ロールには転動疲労によると考えられるスポーリングが発生しロール削量低減の漳害となつている。 このスポーリングを防止するためロール表面に生じる転動疲労層を非破壊的に測定することが望まれて いる。一方、X線回折によつて測定される半価巾と疲労の 進行との間に対応があることが知られている。平 ら゙てよると 鋼線材の回転曲げ疲労について焼鈍材は疲労の進行とともに 表面の半価巾が増加するが、予加工材及び熱処理材飞ついて は表面の半価巾が減少する。

泠延ワークロール表面の疲労層をX 線半価巾を用いて測定 した例はほとんどない。これは冷延ワークロールの表面材質 が硬く疲労損傷を生じにくいと考えられていたことが一因で ある。今回、X線半価巾を利用して冷延ワークロール表面 の疲労曾について測定を行つたので欵告する。

\section{2. 実験方法}

供試ロールは君津製鐵所冷延工場タンデム冷間圧延機に使 用しているワークロールである。性状は表 1 の通り、又最大 接触圧力 $\mathrm{P}_{\max }=105^{\mathrm{Kg}} \mathrm{mm}^{2}$ である。測定は所定量圧延して定 期研削のためロールスタンドから引出したロールの胴中央部 について行つた。ロール表面の他深さ方向分布も測定した。 装置は $\mathrm{S}$ 社製 $\mathrm{X}$ 線応力測定装置を用いた。

測定位置, 結果を図 1 图 3 亿示す。

3. まとめ

(1) 半価巾はロール表面で低下するが、半価巾の変化は口ル表面から $0.1 \mathrm{~mm}$ 以内に限定される。

（2）表面半価巾はロール接触回数が増すとともに減少する。 又、削量を減ずると半価巾が低下するが、これは疲労層 の蓄積のためと考えられる。

参考文献

1) 材料学会：材料, 19, 714

2) 平战: 金属材料, $\underline{2}, 84$

3) Taira et al.: Bul. J SME, 44, 230 (1961)

表 1 冷延ワークロールの性状

\begin{tabular}{|c|c|c|c|c|c|c|c|}
\hline \multirow{2}{*}{ 種 類 } & \multicolumn{5}{|c|}{ 成 分 $(\%)$} & \multirow{2}{*}{\begin{tabular}{|c|} 
表面硬度 \\
$\mathrm{Hs}_{\mathrm{s}}$ \\
\end{tabular}} & \multirow{2}{*}{ 表面買組織 } \\
\hline & $\mathrm{C}$ & $\mathrm{Si}_{\mathrm{i}}$ & $\mathrm{Mn}$ & $\mathrm{Cr}_{\mathrm{r}}$ & $\mathrm{Mo}_{\mathrm{O}}$ & & \\
\hline 鉔造焼入 & 1.0 & 0.3 & 0.3 & 2.0 & 0.3 & $80 \sim 90$ & マルテンサイト \\
\hline
\end{tabular}

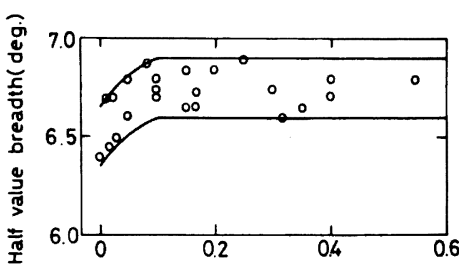

Depth from the roll surface $(\mathrm{mm})$

図 2 半価巾の深さ方向分布

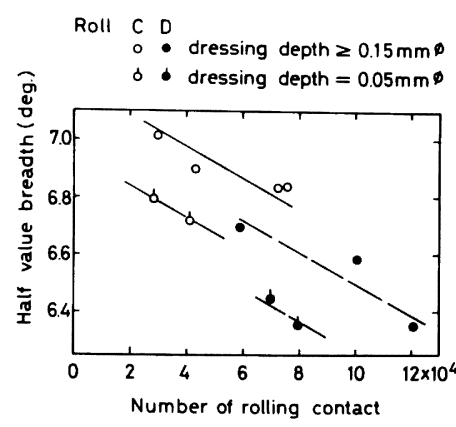

図 3 ロール接触回数之表面半価巾 の関係 
（355）冷延バックアップロールの疲労損傷

（ X 線によるロール損傷の研究一 II )

新日鐵 君津製鐵所

\section{1. いきさつ}

第 1 献では冷延ワークロールについてX線半価巾による転動 疲労層の検出について報告した。本報では冷延バックアップロ ール表面の転動疲労層について報告する。 バックアップロー ルの従来の研究をみると下田ら ${ }^{1)}$ の冷延バックアップロールスリ ーブについての研究及び長瀬ら゙の厚板バックアップロールにつ いての研究がある。両者ともロール表面便度がHs 47 ～50の比 較的㜢質なロールについての研究であり、長瀬らは表面半価巾 が応力くり返し数が増すにつれて増大するとの知見を得ている。

今回、われわれはHs 55 以上の比較的硬質な冷延バックアッ プロールについて調査したので以下に報告する。

\section{2. 実㗑方法}

第 1 報と同様である。結果を図 1 及び図 2 に、ロール接触面 下のHerz 応力分布を図 3 亿示す。

3. まとめ

半価巾の変化はロール表面から $0.3 \mathrm{~mm}$ 以内に限定される。 半価巾変化のパターンは最表面で最大で、深さ $0.2 \mathrm{~mm}$ 附近 で極小を示す。この半価巾の変化は転動疲労によつて生じ たと考えられる。

4. 考 察（（1)，(3)については第1報についても適合する。）

（1）半価巾変化か表面附近に限定されるのは応力が低いため、 表面圧縮応力が半価巾変化に奇与するが、内部剪断応力の 寄与が小さいためと推定される。

(2) 半価巾変化パターンは下田らの結果と同様である。

（3）表面半価巾が接触回数の増加とともに減少するのは長瀬ら の結果と異なるが、これはHs 64 以上の表面硬度のロール では疲労の進行とともに表面半価巾が低下するのに対し、 Hs 50 以下のロールでは表面半価巾が増加するためと考え られる。

参考文献 1) 下田ら：材料試験，11，663（1962）

2）長頼ら: 鉄と鋼, 56,1201 (1970)

表 1 冷延バックアップロールの性状

\begin{tabular}{|c|c|c|c|c|c|c|c|}
\hline \multirow{2}{*}{ 種類 } & \multicolumn{5}{|c|}{ 成 分 (\%) } & 表面硬度 & \multirow{2}{*}{ 表面層組織 } \\
\hline & C & $\mathrm{Si}_{\mathrm{i}}$ & $\mathrm{Mn}$ & $\mathrm{Cr}$ & Mo & $\mathrm{Hs}$ & \\
\hline 鉔銅 & 0.5 & 0.3 & 0.3 & 2.0 & 0.3 & $55 \sim 72$ & ベイナイト \\
\hline
\end{tabular}

工博 武智弘 難波和郎○川崎宏一 古賀国彦 藤原圭三 三堀 勤

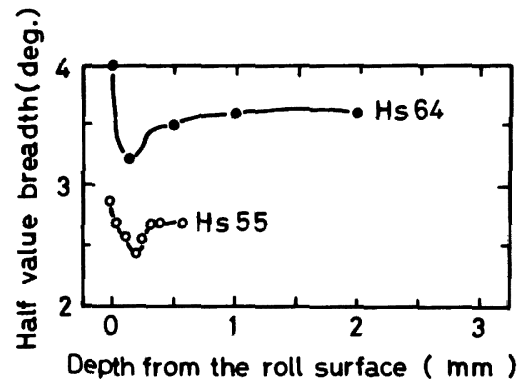

図 1 半価巾の深さ方向分布

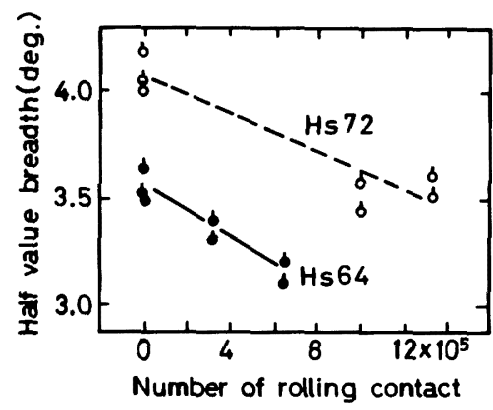

図 2 ロール接触回数と表面半価巾 の関係

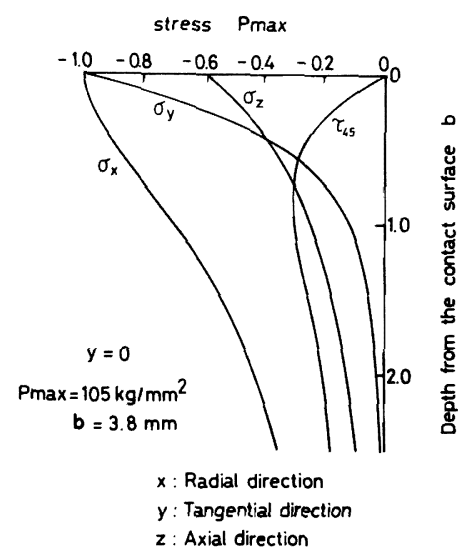

図 3 ロール接触面下の Her $\mathrm{z}$ 応力 分布 
'76-S 356

(356)
620.191: 621.771.07: 621.785.3/.7: 539.24/.25

分塊口ール材の疲労クラック伝播特性を含む

各種強度特性飞及活す熱処理の影響

侏神戸製銓所中央研究所豊田裕至口斎藤 誠 太田定雄

1. 緒言 分塊ロールの折損は表面ファイヤクラックの発生と、それが繰返し氏延荷重によって、疲労クラ ックとして染さ方向へ進展し、最後に脆性的に破損するといら三つの過程に分けて考える事がでする。第一 のファイヤクラックにつロては、ロールが高温の鋼片に接触して繰返し大をな熱応力を受けるため、ロール の寿命に比べると極めて早い時期に発生するが、熱応力は表面付近にしか働かないので、ファイヤクラック は熱応力だけでは染くまで進展せず、その発生特性が全寿命に与充る影䇾はあまり大きくないと言える。ま た最後の恢性的破損については、破壊勒性値を高める事はそれだけ染く進んだ痩労クラックにす折れない事 を意味するが、疲労クラックは深く進む怡ど進展速庶が加速的に增大するので、破買软性值を高めるだけで はそれ恬ど寿命は延びないと考えられる。そ己で、寿命を最す大きく支配するのは疲労クラックの层播特性 であると考充、見在使用されている分塊ロール材について種々の熱処理を施し、各種強度特性とともに、特 飞疲学クラック伝播特性に対する熱処理の影響を調へた。

2. 実験方法 供試材は分塊ロールとして使用される $0.55 \mathrm{c}-1.3 \mathrm{Ni}-1 \mathrm{Cr}-0.3 \mathrm{Mo}$ 䤨鋼であり、実体ロールか ら採取した試料に種々の熱处理を施した。試䮖としては、室温加ら実㗢ロールの表面付近温度と思われる

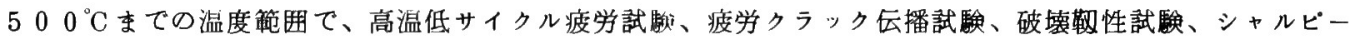
衝揧試験、および高温短時間引張り試験をそれぞれ行った。クラック后播試験にはWOI コンパクトテンシ ヨン型試験片を用い、クラック長さは実体顥微鏡により測定した。

3. 結果図 1 飞代表的な三種の熱処理条件に対する䫓微鏡組織写真を示す。全歪量一定の条件では高温低

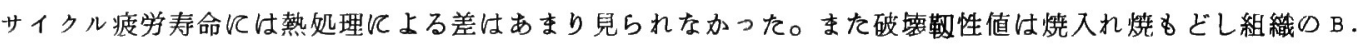

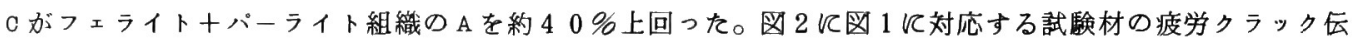
播特性を示す。 $690^{\circ} \mathrm{C}$ て焼戻した焼入れ焼戻し組織の B はつェライト+パーライト組織の A $650^{\circ} \mathrm{C} て$

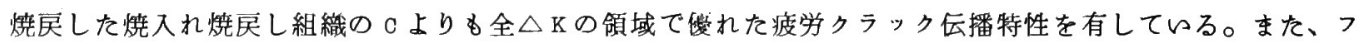
ェライト十パーライト組織の $\mathrm{A}$ と焼入れ焼戻し組織の $\mathrm{C}$ とは $\triangle \mathrm{K}$ の領域によっては云播速度の大小関係が逆 転するので、この上うな場合には実際のロールの荷重条件（ $\triangle \mathrm{K}$ の範囲）を考虑して比較する必要がある。 てれらの結果加ら、実体ロ一ルにおいて疲労クラック伝 播特性が問題となる部分に適正な熱処理を施す事によっ て、分塊口一几の耐折損寿命を大きく改善する事が期待 される。

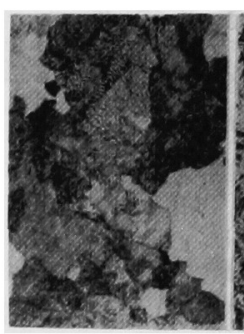

A Hv 240 $900^{\circ} \mathrm{C}$ 烧了斻 $650^{\circ \mathrm{C}}$ 烧比光

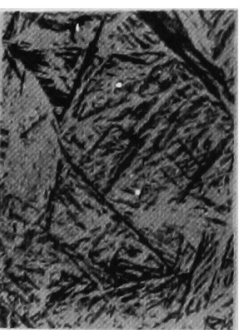

B Hv 280

\section{$900^{\circ} \mathrm{C}$ 烧入} $690^{\circ} \mathrm{C}$ 烧七ど

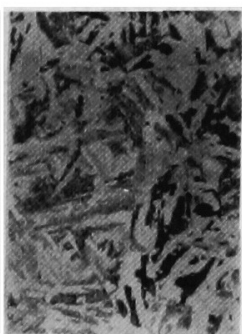

C $\mathrm{H}_{\mathbf{V}} 350$ $900^{\circ} \mathrm{C}$ 烧入n $650^{\circ} \mathrm{C}$ 烧好

四 1. 顕微鏡組織 $(\times 240)$ 及び硬度

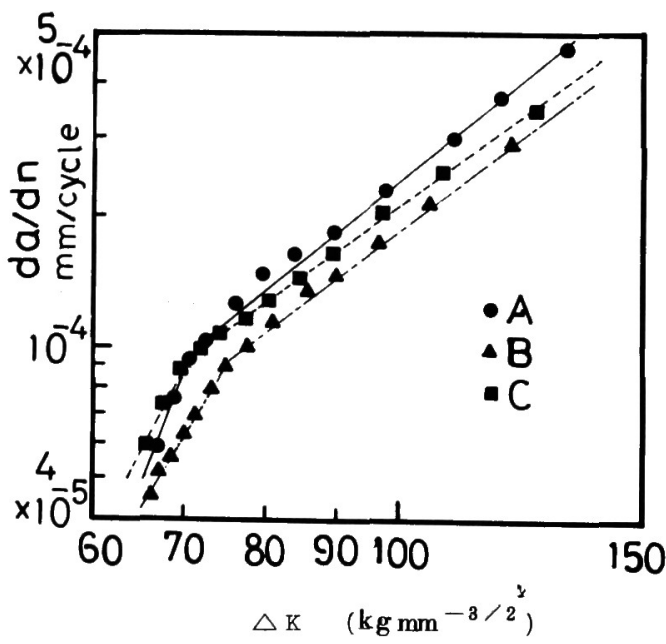

図2. 疲労クラック伝播特性 
（357）銅の疲れ毫裂伝播速度におよばすブレクラッキングサイクルの効果

\section{東京工業大学精研。布村成具 大学院山下哲二}

\section{上緒言}

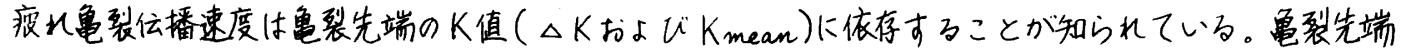
の応力はこれより充分離れている点に比べて充分に大きいので皇裂進行以前に之の材料が受けた疲れ

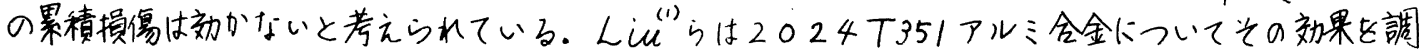

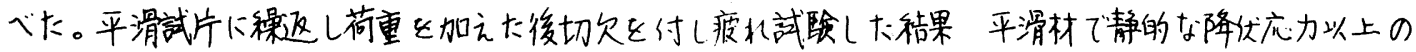
過大応力での緗返し(プレクラッキングサイクル)は切次付与後の疲れ艎裂位播速度を早めるが、長寿

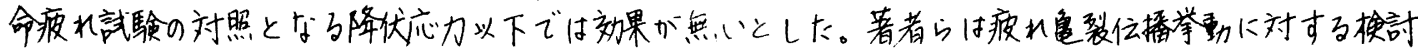
から低 $\Delta K$ 值側では降状応力以下のプレクラッキングサイクルでも効果のあることを予测し7075 T6

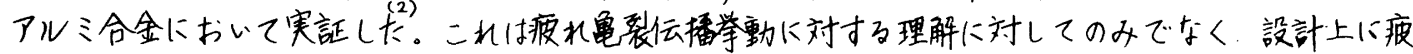
れ毫裂伝播速度をとり入れたfail safe 設計において重要な问題と考え的水のて 銅についても同 槏古実駼を行ない，予想された結果か得られたのてここに報告する。

\section{2. 方法}

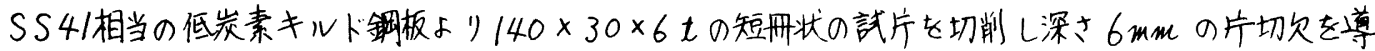

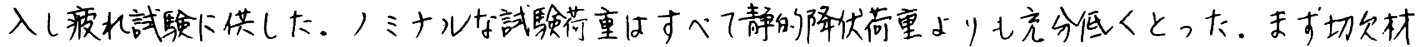
にある荷重で4万回ないし8万回貝荷し、裂の用始し ない場合、それよりも高的荷重て疲北試験を行子山疲北 笔伝播速度を测定する。次に最初から二の後者の筫荷 条件で疲北試験を行ない, 前の試駼結果と比較する。

\section{3 结果之検討}

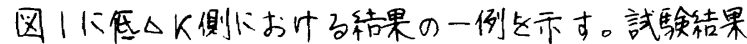

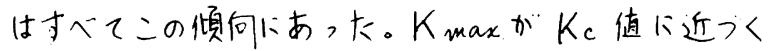

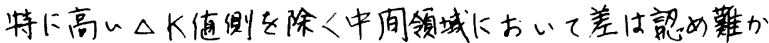

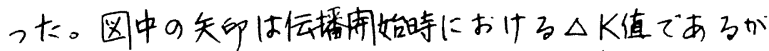
伝播南始後PC材はある低い速度て妘播をを同始するが。 $\triangle K$ の增加下伴山速度を急激下上师定常状態下连する。 非 P C 材はより低い伝播速度より伝播を始め，PC林よ リかなり高い

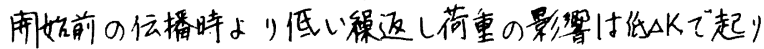

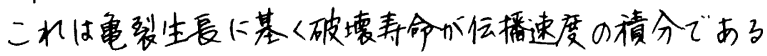
ことを考虑す北ば結果に大きく影警することが判る。こ のP C 試片と非P C 試片の非定常域の差黑は，破面䘽察

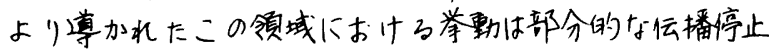
の租合世上する著者的の考えと一致する。す古らち cumulated damage が伝播のprobability を增す

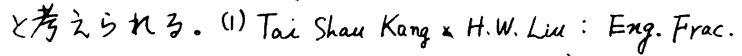
Mech. 6 (1974) 63/ 638

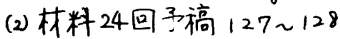

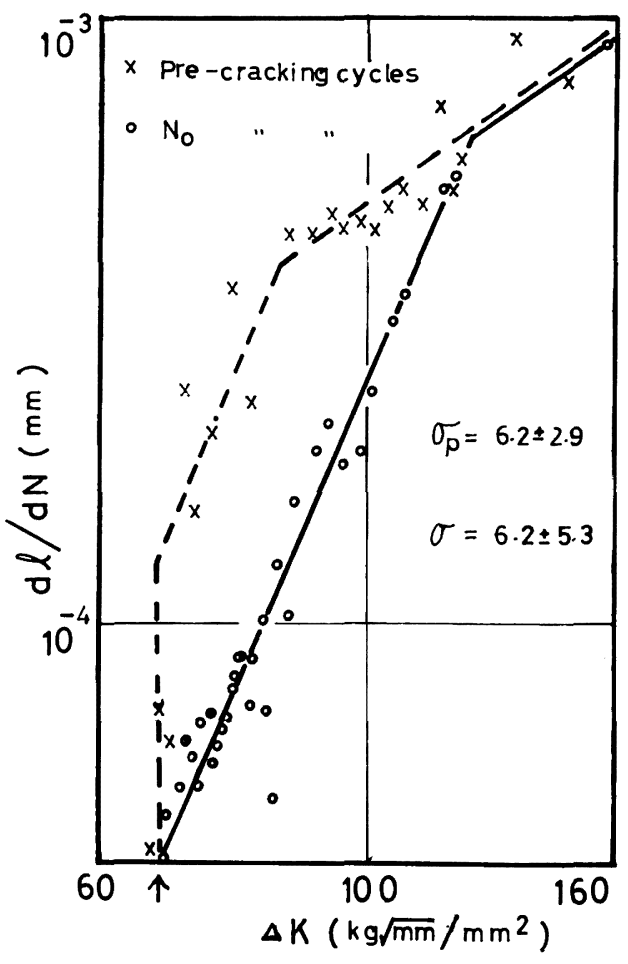

図1，低 $\Delta K$ 側におけるプレクラッキングサ イクルの初果. NP $=40000$ SS41铜 
'76-S $358669.14 .018 .292: 620.178 .311 .81: 620.194 .8$

\section{（358）低繰返し速度における鋼材の腐食疲労強度に及ほすす切欠の影響について}

（鋼材の腐食疲労に関する研究 一第 2 報一）

新日本製鐵株式会社

製品技術研究所

\author{
門 智 石黒隆義 \\ ○石井伸幸関口 進
}

1. 粕言：鋼材の腐食疲労強度は繰返し速度に依存する。したがって, 腐食性環境下において荷重の 絽返しをうける部材の疲労強度は, 部材に作用する荷重の繰返し速度条件下で求めなければならない。た とえば，波浪を対象とする場合の絽返速度は約 $10 \mathrm{cpm}$ である。このような低繰返し速度での疲労試験は， 試験期間が極めて長期にわたる。そこで，著者らは同時に多数の試験が出来るように製作した腐食疲労試 験装置を用いて, 繰返し速度が $10 \mathrm{cpm}$ における海水中での各種鋼材の疲労特性を求め, 前報で報告した。 一方，鋼の疲労強度に及ぼす切欠の影響に関するデータは，これまでに多数報告されている。しかしなが ら，これらのデータは大気中のものが多く，とくに低綝返し速度における腐食疲労特性に及ぼす切欠の影 響に関するデータは少ない。一般に，腐食疲労においては切欠の影響が小さくなることが知られているが, 大気中における切欠作用との関係で腐食疲労における切欠の影響を検討したデータは極めて少ない。本報 告は前報に続いて，低繰返し速度下での各種鋼材の腐食疲労特性に及ぼす切欠の影響を検討した結果であ る。

2、試験の内容：供試材および試験片は前報に示した通りで, 引張強さが約 $47 \mathrm{k} g / \mathrm{mm}^{2}$ から約 $108 \mathrm{~kg}$ $/ \mathrm{m}^{2}$ までの 5 鋼種であり, 試験片は平滑試験片および応力集中係数 $\mathrm{Kt}$ を $2,3,5$ の三段階に変えた切欠 試験片である。人工海水中での腐食疲労試験は前報と同様であり, 大気中の疲労試験は絽返し速度を

$1800 \mathrm{cpm}$ で行なったほかはすべて腐食疲労試験と同じ条件で行なった。

3. 試験結果：破壊までの繰返し数 Nf が $5 \times 10^{5}$ での主な結果は以下の通りである。

(1) 応力集中係数 $\mathrm{Kt}=2$ では, 引張強さが約 $74 \mathrm{~kg} / \mathrm{mm}^{2}$ までは大気中における切欠係数 $\beta(=\sigma \mathrm{w} / \sigma \mathrm{wk})$

よりも海水中における切欠係数 $\beta \mathrm{c}\left(=\sigma_{\mathrm{wc}} / \sigma_{\mathrm{wk}} \mathrm{c}\right)$ の 方が大きい。

(2) $\mathrm{Kt} \geqq 3$ では軟鋼である $\mathrm{A}$ 鋼の $\beta$ は $\beta \mathrm{c}$ にほぼ等 しいが, 引張強さが約 $54 \mathrm{k} g / \mathrm{mm}^{2}$ 以上になると $\beta>$ $\beta c$ なる関係を示す。

(3) 引張強さが約 $74 \mathrm{~kg} / \mathrm{mm}^{2}$ 以下では, 腐食係数 $\mathrm{fc}\left(=\sigma_{\mathrm{w}} / \sigma_{\mathrm{wc}}\right.$ または $\left.\sigma_{\mathrm{wk}} / \sigma_{\mathrm{wk} \mathrm{c}}\right)$ は $\mathrm{K} \mathrm{t}=2$ で最大 値を示し，K t が大きくなると腐食係数は小さくなり， 一定値に近づく傾向を示す（図 1 )。

(4) 引張強さが約 $108 \mathrm{~kg} / \mathrm{mm}^{2}$ の $\mathrm{E}$ 鋼の腐食係数 $\mathrm{fc}$ は $\mathrm{Kt}=1.0$ で最も大きく， $\mathrm{Kt}$ が大きくなるととも に腐食係数は小さくなる(図 1 )。すなわち，腐食疲 労強度に及ぼす腐食の影響は引張強さが約 $74 \mathrm{k} g / \mathrm{m}^{2}$ までは $\mathrm{Kt}=2$ において最大であり, 引張強さが約 $108 \mathrm{~kg} / \mathrm{mm}^{2}$ になると $\mathrm{kt}=1.0$ で最大值を示す。 (記号の説明)

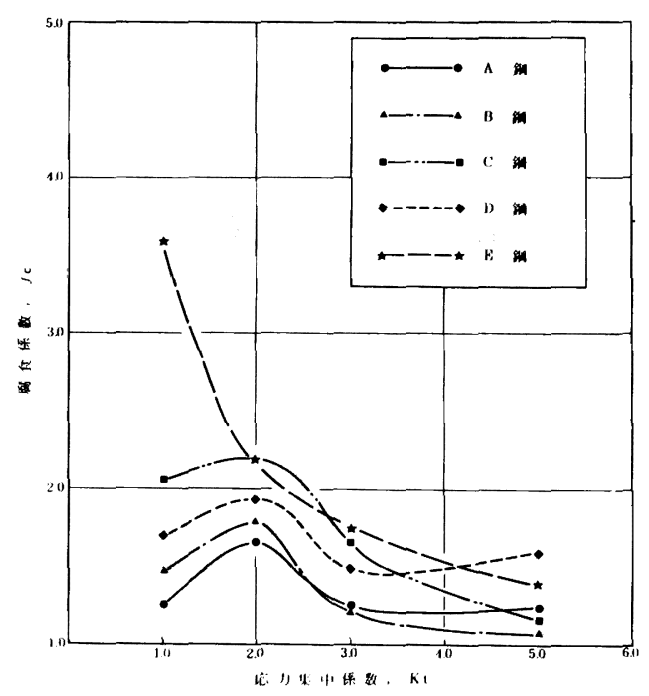

図 1 応力集中係数と腐食係数の関係

$\sigma_{\mathrm{w}}, \sigma_{\mathrm{wk}}$ : それぞれ平滑材および切欠材の大気中における披労強度

$\sigma_{\mathrm{wc}}, \sigma_{\mathrm{wk} \mathrm{c}}$ : それぞれ平滑材および切欠材の海水中における疲労強度

1) 門, 石黒, 石井, 関口, 鉄と鋼 Vol.61 No.12 P. 336(1975) 
$669.15 \cdot 26-194.57: 620.178 .311 .8: 536.423 .15$

$620.193 .27: 620.193 .25$

'76-S 359

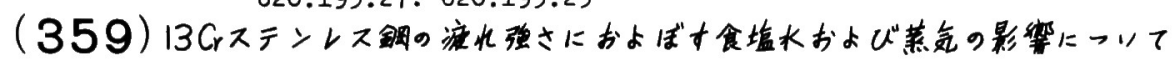

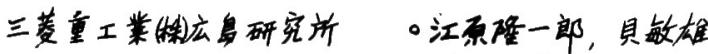 应身造船所模村雅䩪}

\section{1 緒言}

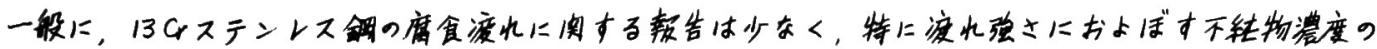

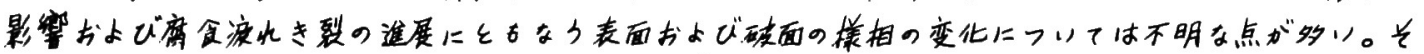

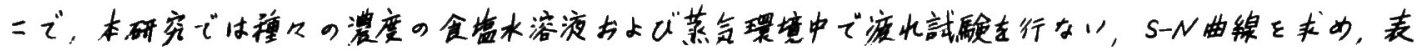
面およで破面の詳細な䂓察を行なった。

2. 实験方法

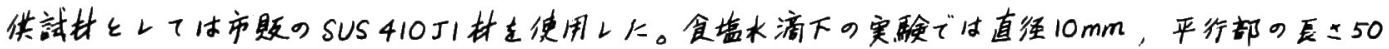

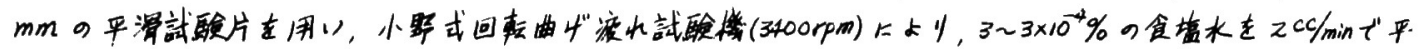

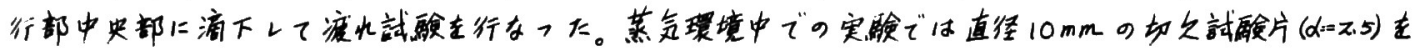

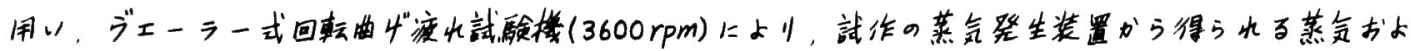

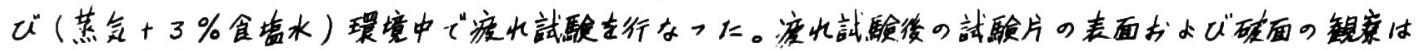
主とレて走查型電㩆により詳细に行なつた。

\section{3. 实臨秥果}

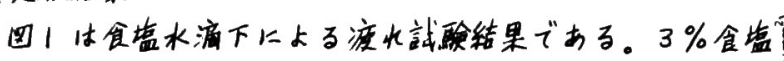
水の影第は影著で，107回の時间強さは大氛中の约1/4に低下

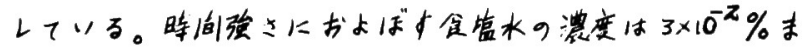

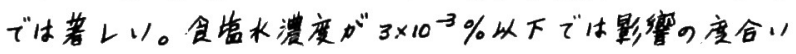
が小さくなるが、全く影鹤っない蒸留水に比べれな゙10回の

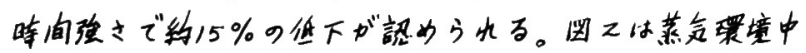

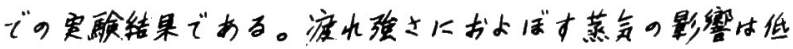
サイクル側はを゙著レく，高茾イクルにはるにレトがフて小

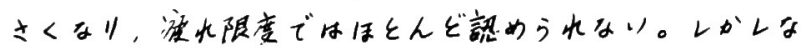

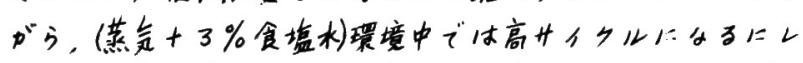

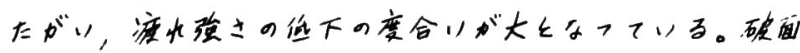
镍察の转果では，大気中および蒸留水滴下による破面では

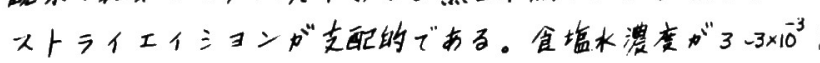

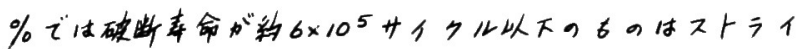

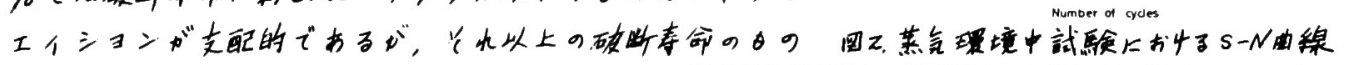
には粒界破面が現水ることを䐂めた。レーレるが

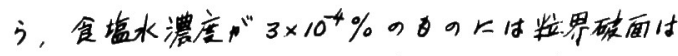

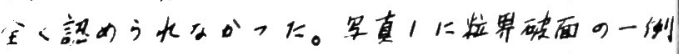
走示す。表面ピツトは全ての環境中での試験片に

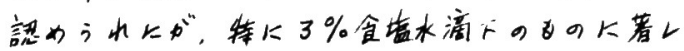

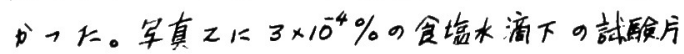
上是う水た表面ピットをサブクラックを六す。

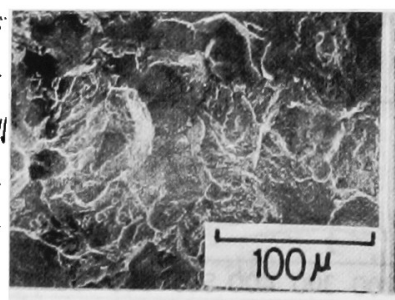

军1. 粒早破而 ( $3 \% \mathrm{Na} \alpha)$ $\sigma=9 \mathrm{~kg} / \mathrm{mm}^{2}, 14=2.5 \times 10^{7}$

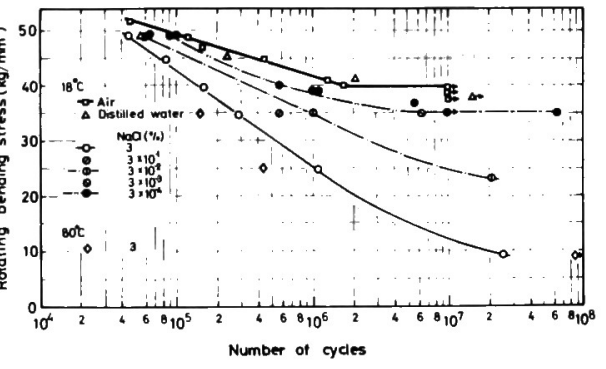

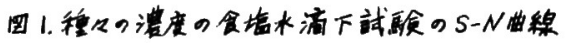

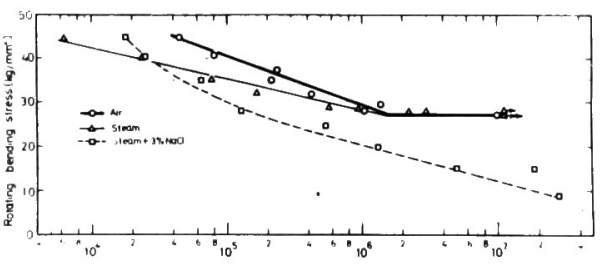

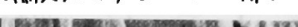

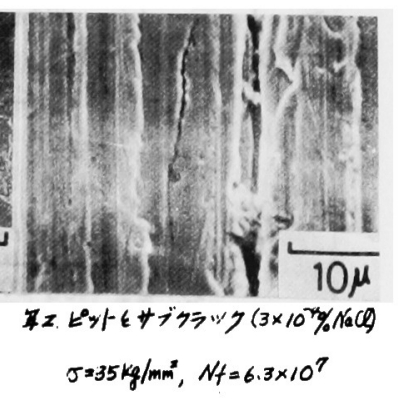


'76- S 360

$621.785 .616: 625.2 .012 .1: 620.178 .3$

669.14.018.29: $539.4 .014 .11: 539.53$

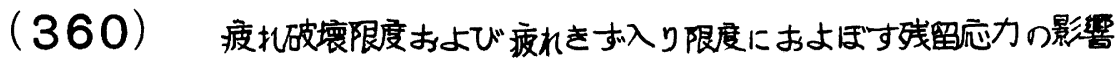

（低温烓入れによる車軸圧入郡の疲孔強さ向上一1）

鉄道枝衔研究所

○高梧良治 佐前初吉

吉村照男工博飯岛一昭

\section{1.緒 言}

銅のA，变態点直下から急冷する低温烧入処理は、表面圧縮残留応力の形成、あるいはフェライ十相

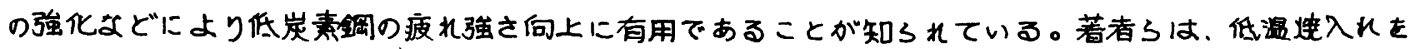

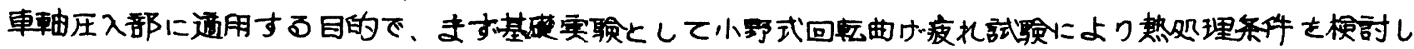

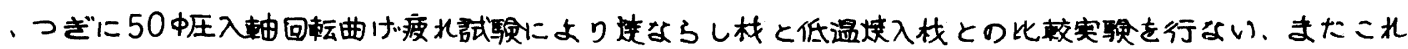
に阅逨して残留応力分布、硬さ特性るどについても検討したので、その結果を報告する。

2. 供試栰料およひ实险方法

供試栰料は小野式回転曲小疲北試睌片に対してはS38Cを、50 中圧入軸に対しては S40Cを用い850

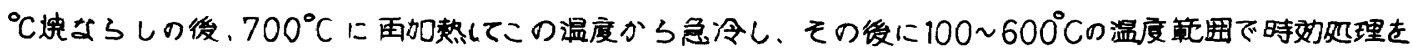

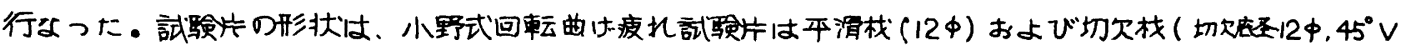

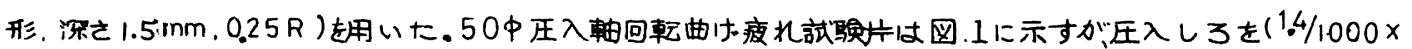

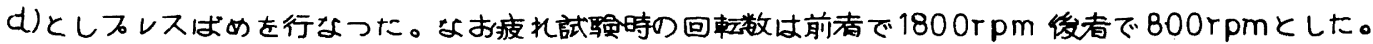
3. 実憕結果

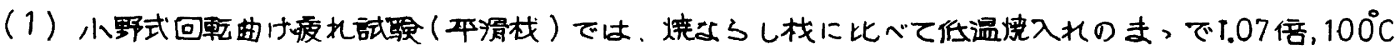

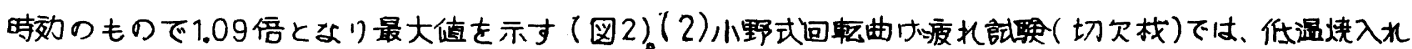

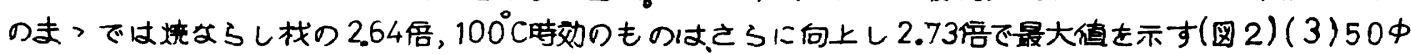

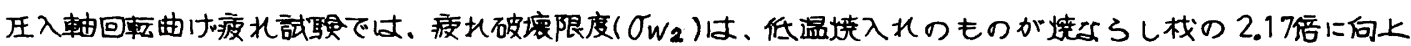

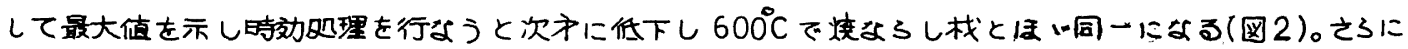

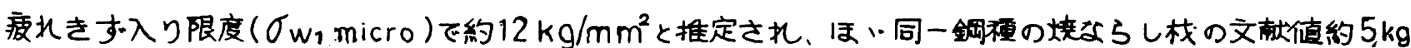

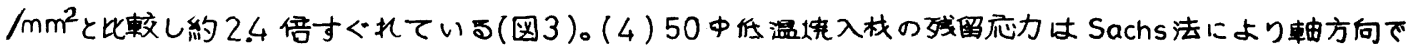
約 $10 \mathrm{~mm}$ 深さまで $20.30 \mathrm{~kg} / \mathrm{mm}^{2}$ の压綰残留応力が分布している 。したがって低温境入れが軸圧入部の疲北強さを向上する原因 过、急冷にさる表面圧縭残留应力の形成と，表面における桪効 硬化との交互作用によるものと考えるれる。
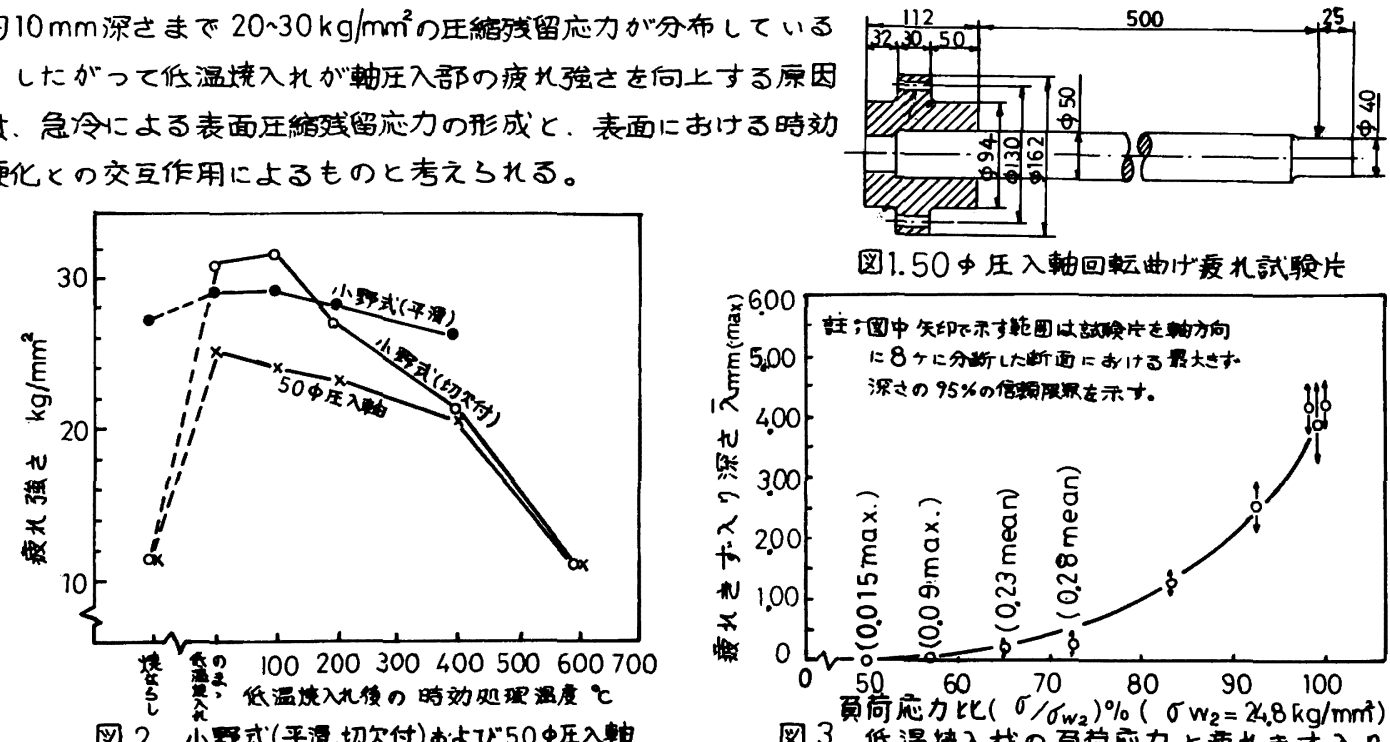

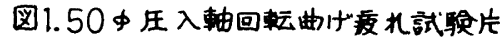

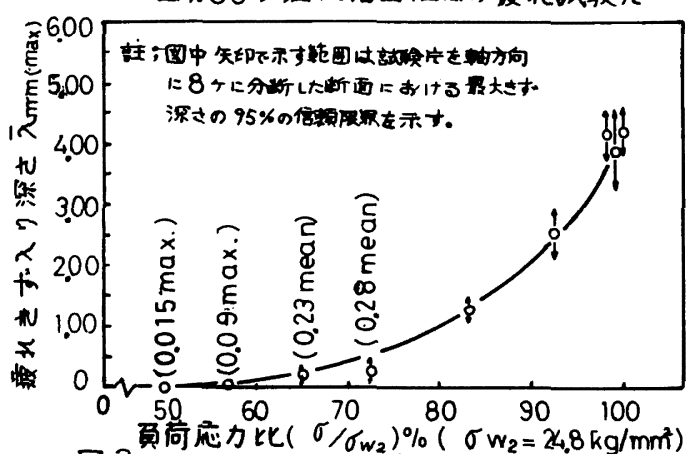

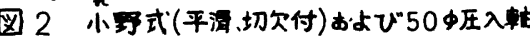

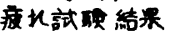

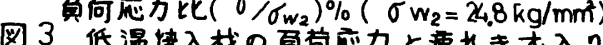
深さ(停留)との我你 $\left(N=2.06\right.$ 209 $10^{7}$ 後) 